\title{
RANCANG BANGUN ALAT PENDETEKSI DAN PEMBERI PERINGATAN KEBISINGAN SUARA BERBASIS ARDUINO (STUDI KASUS: PERPUSTAKAAN UNIVERSITAS AMIKOM PURWOKERTO)
}

\author{
Charir Maulana Achsan \\ Fakultas Ilmu Komputer, Program Studi Teknik Informatika \\ Universitas AMIKOM Purwokerto \\ Email: charirmaachsan@gmail.com \\ Dwi Krisbiantoro \\ Fakultas Ilmu Komputer, Program Studi Sistem Informasi \\ Universitas AMIKOM Purwokerto \\ Email: dwikris@amikompurwokerto.ac.id
}

\begin{abstract}
ABSTRAK
Perpustakaan merupakan salah satu sarana menggali informasi, belajar dan berdiskusi, oleh karena itu harus dijaga dari faktor-faktor yang dapat mengganggu kenyamanan karena kenyamanan sangat berperanguh dalam berkonsentrasi sehingga kegiatan membaca maupun berdiskusi berjalan dengan maksimal. Salah satu faktor yang menggangu dalam proses belajar baik itu membaca dan berdiskusi adalah kebisingan. Dalam melakukan tindakan pencegahan kebisingan petugas Perpustakaan Universitas AMIKOM Purwokerto masih menggunakan cara konvensional yaitu dengan menegur pengunjung perpustakaan yang melakukan kebisingan. Hal ini belum efektif jika terus karena petugas perpustakaan tidak bisa setiap saat menegur pengunjung yang melakukan kebisingan karena pengunjung itu sendiri sering melakukan kebisingan yang berulang hal ini dapat menganggu kegiatan kerja yang dilakukan oleh petugas perpustakaan. Jika kebisingan tersebut dibiarkan terlalu lama akibatnya akan menggangu konsentrasi pengunjung dalam membaca dan melakukan diskusi. Tujuan dari pembuatan alat ini yaitu terbentuknya Alat Pendeteksi dan Pemberi Peringatan Kebisingan Suara Berbasis Arduino sebagai salah satu upaya membantu staf perpustakaan dalam hal mengontrol atau mengendalikan kenyamanan ruangan Perpustakaan Universitas AMIKOM Purwokerto dari kebisingan yang berlebihan. Metode pengembangan sistem yang digunakan pada penelitian ini adalah prototype. Hasil pengujian dari alat ini dapat mendeteksi kebisingan suara sekaligus memberi peringatan berupa teks dan audio.
\end{abstract}

Kata kunci: perpustakaan, kebisingan, prototype, arduino

\begin{abstract}
Library is one of the media to delve information, study and discuss, therefore it must be protected from factors that can interfere with comfort because comfort is very influential in concentrating so that reading and discussion activities can run optimally. One of the factors that can interfere the learning process both reading and discussing is noise. In carrying out noise prevention, the library staff of the AMIKOM University in Purwokerto still uses the conventional method which is reprimanding library visitors who make noise. This has not been effective if it continues because library staff cannot at any time reprimand visitors who make noise because visitors themselves often making noise repeatdely, this can disrupt the work activities carried out by library staff. If the noise is left too long the consequences will disrupt the concentration of visitors in doing reading and discussions. The purpose of making this tool is to built a Prototype of Arduino-based Noise Detection and Noise Warning as an effort to helping library staff in term of controlling the comfort inside University Of AMIKOM Library room from excessive noise.. The sistem development method used in this research is prototype. The test results of this tool can detect noise as well as give a warning in the form of text and audio.
\end{abstract}

Keywords: library, noise, prototype, arduino 


\section{PENDAHULUAN}

Pada masa kini, teknologi telah masuk kedalam setiap aspek kehidupan manusia.. Kemajuan teknologi yang pesat dapat membantu manusia dalam melakukan segala kegiatan seperti membantu dalam penyelesaian suatu masalah. Salah satu teknologi yang bermanfaat bagi manusia adalah Mikrokontroler. Mikrokontroler dapat digunakan untuk membantu pekerjaan manusia sehingga pekerjaan yang dilakukan menjadi efektif dan efisien sehingga dapat menghemat waktu dan tenaga yang digunakan. Perpustakaan merupakan salah satu sarana menggali informasi, belajar dan berdiskusi, oleh karena itu harus dijaga dari faktor-faktor yang dapat mengganggu kenyamanan karena kenyamanan sangat berperanguh dalam berkonsentrasi sehingga kegiatan membaca maupun berdiskusi berjalan dengan maksimal. Menurut Hakim (2014), "Kenyamanan adalah segala sesuatu yang memperlihatkan penggunaan ruang secara harmonis, baik dari segi bentuk, tekstur, warna, aroma, suara, bunyi, cahaya, atau lainnya" [1]. Sedangkan faktor-faktor yang mempengaruhi kenyamanan antara lain yaitu unsur sirkulasi, daya, alam/iklim, kebisingan, aroma/bau-baun, bentuk, keamanan, kebersihan, keindahan dan penerangan [2]. Kebisingan dapat didefinisikan sebagai segala suara baik itu suara lembut ataupun keras yang dapat menggangu dan tidak diharapkan oleh manusia [3]. Berdasarkan pengaruhnya terhadap manusia, kebisingan dapat dibagi menjadi 3 jenis yaitu: bising yang menggangu (irritating noise), bunyi yang menutupi (masking noise) dan bunyi yang merusak (damaging/injurious noise) [4]. Secara konseptual pengendalian kebisingan dapat dilakukan pada 3 (tiga) sektor yaitu pengendalian kebisingan pada sumber kebisingan, pengendalian kebisingan pada jejak propogasi, dan pengendalian kebisingan pada manusia [5].

Perpustakaan Universitas AMIKOM Purwokerto merupakan salah satu unit pelaksana teknis yang dimiliki Universitas AMIKOM Purwokerto. Perpustakaan ini berdiri bersamaan dengan berdirinya STMIK AMIKOM Purwokerto pada tahun 2005. Lokasi Perpustakaan ini terletak di lantai 2 gedung Universitas AMIKOM Purwokerto. Perpustakaan Universitas AMIKOM Purwokerto mempunyai tugas memberikan pelayanan kepustakaan seperti peminjaman buku, pengecekan penulisan skripsi, penyediaan layanan internet dan lain-lain.

Kebisingan pada ruangan Perpustakaan Universitas AMIKOM Purwokerto masih terjadi terutama pada jam sibuk yaitu antara jam 9 pagi sampai jam 3 sore menurut Staff Bidang Pengolahan dan Pengadaan Koleksi. Sumber kebisingan yang paling utama yaitu dari pengunjung itu sendiri. Petugas perpustakaan sudah melakukan upaya untuk mengatasi masalah ini dengan cara memberi teguran terhadap pengunjung yang melakukan kebisingan, tetapi cara itu belum efektif karena petugas perpustakaan tidak bisa setiap saat menegur pengunjung yang melakukan kebisingan karena pengunjung itu sendiri sering melakukan kebisingan yang berulang hal ini dapat menganggu kegiatan kerja yang dilakukan oleh petugas perpustakaan. Jika kebisingan tersebut dibiarkan terlalu lama akibatnya akan menggangu konsentrasi pengunjung dalam membaca dan melakukan diskusi.

Berdasarkan masalah tersebut perlu dibuat penelitian yang berkenaan dengan Prototype Alat Pendeteksi dan Pemberi Peringatan Kebisingan Suara Berbasis Arduino. Alat ini akan mendeteksi tingkat kebisingan suara sesuai dengan standar kebisingan perpustakaan yaitu berkisar 45-55dB (KepMenLH, 1996) [6].

Salah satu penelitian yang telah dilakukan untuk menanggulangi kebisingan yaitu penelitian yang dilakukan oleh (Nurwati, 2018) dengan judul "Pendeteksi Tingkat Kebisingan dan Pemberi Peringatan Pada Perpustakaan berbasis Arduino". Penelitian ini menggunakan sensor suara LM393, LCD 16x2, sebagai pemberi peringatan menggunakan LED dan Modul ISD1820 beserta speaker berdaya 0.5 watt [7]

Alat yang digunakan dalam penelitian ini nantinya akan dilengkapi dengan sensor suara berbasiskan chip MAX4466. Pemilihan sensor suara berbasiskan chip MAX4466 dibandingkan dengan sensor suara yang lain seperti LM393 mempunyai alasan yaitu karena MAX4466 adalah sebuah chip op-amp, mempunyai amplifier dan chip op-amp MAX4466 ini adalah chip yang dioptimalisasi untuk digunakan dalam microphone amplifier, Sedangkan LM393 adalah sebuah chip dual different comparator, tidak mempunyai amplifier dan chip LM393 secara teori hanya dapat digunakan untuk mendeteksi suara yang keras saja seperti tepukan dan ketukan. Alat ini juga dilengkapi dengan speaker subwoofer sebagai pemberi peringatan kebisingan berupa suara peringatan penggunaan jenis speaker ini mempunyai alasan agar peringatan suara bisa terdengar dalam ruangan yang cukup luas dan sebuah layar OLED berukuran 128x64 pixel sebagai penampil nilai desibel sekaligus pemberi peringatan berupa tulisan peringatan (warning text). 
Layar OLED dipilih karena menggunakan sumber daya lebih hemat dan kecerahan yang lebih terang dari pada layar LCD. Alat ini akan ditenagai menggunakan Adaptor, hal ini dipilih karena Adaptor mempunyai keuntungan yaitu praktis digunakan karena sumber tegangan AC dapat banyak ditemukan diberbagai tempat dan tidak diperlukannya penggantian dan pengisian baterai. Alat ini nanti akan bekerja dengan mendeteksi tingkat kebisingan dalam satuan decibel dan akan memberikan peringatan berupa warning text dan peringatan suara jika nilai decibel berada diatas nilai $55 \mathrm{~dB}$.

\section{METODOLOGI PENELITIAN}

Untuk mewujudkan suatu alat dan system pendeteksi kebisingan dan pemberi peringatan suara berbasis Arduino, maka pada bagian ini akan dijelaskan tentang kerangka berpikir dan alat-alat yang digunakan dalam penelitian.

\subsection{Kerangka Berpikir}

Kerangka berpikir penelitian yang dilakukan dalam penelitian ini dipaparkan pada diagram alir di gambar 1.

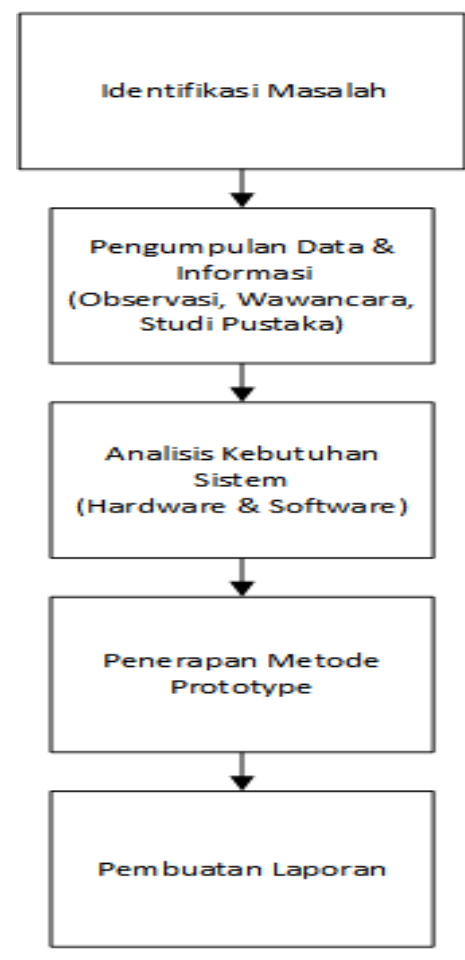

Gambar 2.1. Diagram Kerangka Berpikir Penelitian

Kerangka berpikir peneliti pada gambar 2.1 dapat dijelaskan sebagai berikut:

\section{a. Identifikasi Masalah}

Tahapan identifikasi masalah merupakan tahapan awal peneliti untuk mengidentifikasi masalah pada objek yang diteliti dan merumuskan permasalahan untuk dijadikan latar belakang dalam penelitian. 


\section{b. Pengumpulan Data \& Informasi}

Pada tahap ini peneliti melakukan pengumpulan data dan informasi yang diperlukan. Teknik pengumpulan data yang digunakan peneliti antara lain sebagai berikut:

1) Observasi

Melakukan pengamatan terhadap objek penelitian yaitu Perpustakaan Universitas AMIKOM Purwokerto

2) Wawancara

Peneliti melakukan kegiatan wawancara dengan bapak Wahyudi, A.Md selaku selaku petugas Perpustakaan AMIKOM Purwokerto. Peneliti melakukan wawancara ini untuk mengumpulkan data data yang diperlukan dalam penelitian.

3) Studi Pustaka

Pengumpulan data dan informasi yang berhubungan dengan penelitian yang dilakukan. Dalam hal ini peneliti mengumpulkan data dari junal, internet, buku, E-book, datasheet, dan lain sebagainya.

\section{c. Analisi Kebutuhan Sistem}

Setelah memperoleh data dan informasi yang diperlukan, tahapan selanjutnya yaitu menganalisis kebutuhan sistem supaya dapat membuat alat prototype dan sistem.

Dalam penelitian ini akan dianalisis semua kebutuhan dari Arduino mulai dari software dan hardware. Analisis hardware secara menyeluruh berfungsi untuk meminimalkan dana dan memaksimalkan fungsi kerja dari alat yang nantinya akan dibuat. Memilih software yang cocok untuk kebutuhan design dan penulisan kode program

\section{d. Penerapan Metode Prototype}

Model prototype dapat digunakan untuk menyambungkan ketidakpahaman pelanggan mengenai hal teknis dan memperjelas spesifikasi kebutuhan yang diinginkan pelanggan kepada pengembang perangkat lunak.

\section{e. Penulisan Laporan}

Tahapan akhir dari proses penelitian ini kemudian di- dokumentasikan ke dalam bentuk tulisan ilmiah. Pada laporan ini terdapat kesimpulan dan saran untuk penelitian selanjutnya.

\subsection{Alat Penelitian}

Alat yang digunakan dalam proses penelitian ini adalah sebagai berikut:

a. Perangkat Keras (Hardware) yang digunakan dalam penelitian ini dapat dilihat pada table 2.1 sebagai berikut:

Tabel 2.1 Perangkat Keras (Hardware) Yang Digunakan

\begin{tabular}{|c|c|c|}
\hline No & Hardware & Satuan Jumlah \\
\hline 1 & Laptop Thinkpad X230 2.6 GHz / 8 GB & 1 \\
\hline 2 & Solder & 1 \\
\hline 3 & Timah solder & Menyesuaikan kebutuhan \\
\hline 4 & Kabel Jumper & 1 \\
\hline 5 & Kabel USB A to USB B & 1 \\
\hline 6 & Obeng & \\
\hline
\end{tabular}

b. Perangkat Lunak (Software) yang digunakan dalam penelitian ini sebagai berikut:

1) Aplikasi editor program : Arduino IDE 1.8.5

2) Software pendukung : Microsoft Visio 2016, Fritzing, Audacity 


\section{HASIL DAN PEMBAHASAN}

\subsection{Flowchart Program}

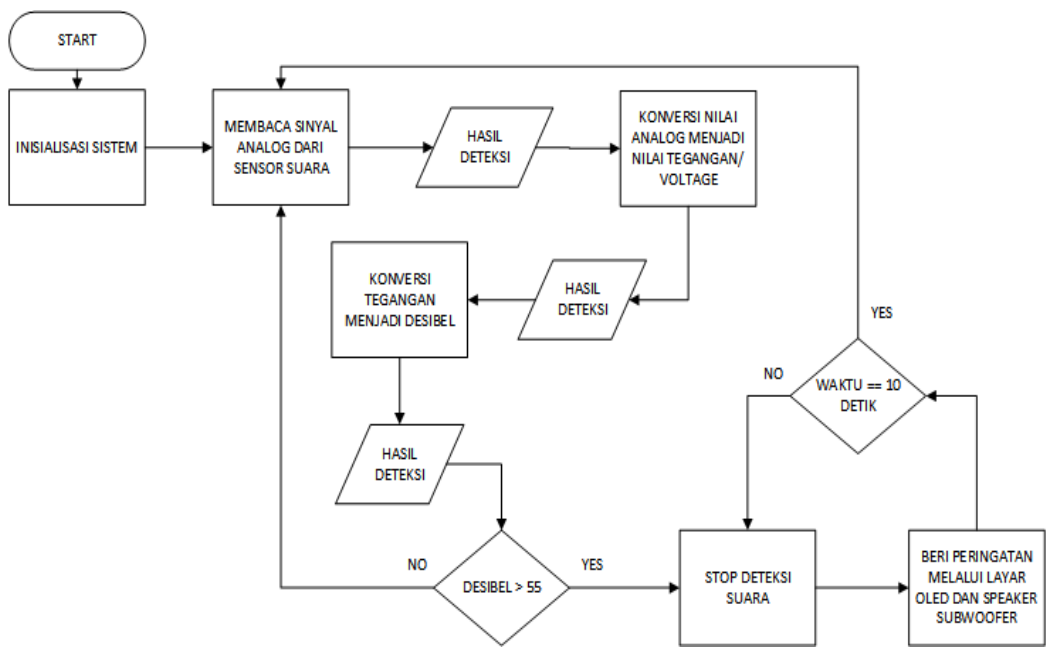

Gambar 3.1. Flowchart Program

Berdasarkan flowchart diatas bisa dilihat bahwa cara kerja alat akan dimulai dengan melakukan inisialisasi sistem yang didalamnya termasuk inisialisasi sound sensor, layar oled, dan inisialiasi modul mp3 player YX5300 beserta MicroSD. Setelah itu dilakukan pembacaan nilai analog yang dihasilkan oleh sensor suara lalu dikonversi menjadi tegangan atau volt yang selanjutnya akan dikonversikan lagi menjadi satuan desibel $(\mathrm{dB})$. Setelah melakukan pengkonversian nilai analog dari sensor suara hingga menjadi nilai desibel proses selanjutnya yaitu menampilkan nilai desibel ke dalam layar OLED 128x64 pixel. Lalu dilanjutkan pembacaan nilai desibel apakah nilai desibel melewati nilai 55dB atau tidak, jika melewati maka alat akan menghentikan pembacaan nilai desibel lalu selanjutnya memberi peringatan berupa teks di layar OLED 128x64 dan berupa suara menggunakan speaker subwoofer. Proses memberi peringatan ini berlangsung selama 10 detik, jika peringatan sudah selesai dilakukan maka alat akan membaca nilai desibel lagi.

\subsection{Perancangan Sistem}

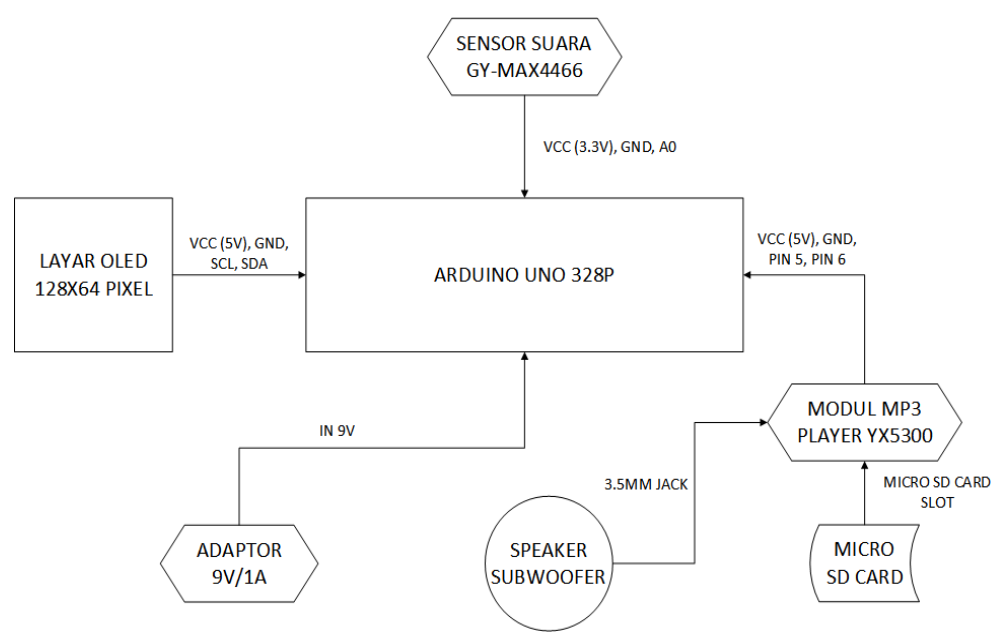

Gambar 3.2. Perancangan Sistem 
Dari gambar 3.2 diatas dapat dijelaskan terdapat berbagai komponen piranti yang berperan masingmasing sebagai input, proses, dan output.

1) Perangkat Input
a. Adaptor 9V
Merupakan pemberi tegangan utama untuk Arduino Uno 328P
b. Sensor suara GY-MAX4466
Sensor yang digunakan untuk mendeteksi dan membaca nilai analog.

2) Proses

Data dari pembacaan sensor suara dikirim dan diproses ke Arduino Uno 328P akan dikonversikan menjadi nilai dengan satuan desibel.

3) Perangkat Output

Output berupa peringatan berupa warning text dan peringatan suara melalui perangkat layar OLED 128x64 pixel dan speaker subwoofer.

\subsection{Skematik Rangkaian}

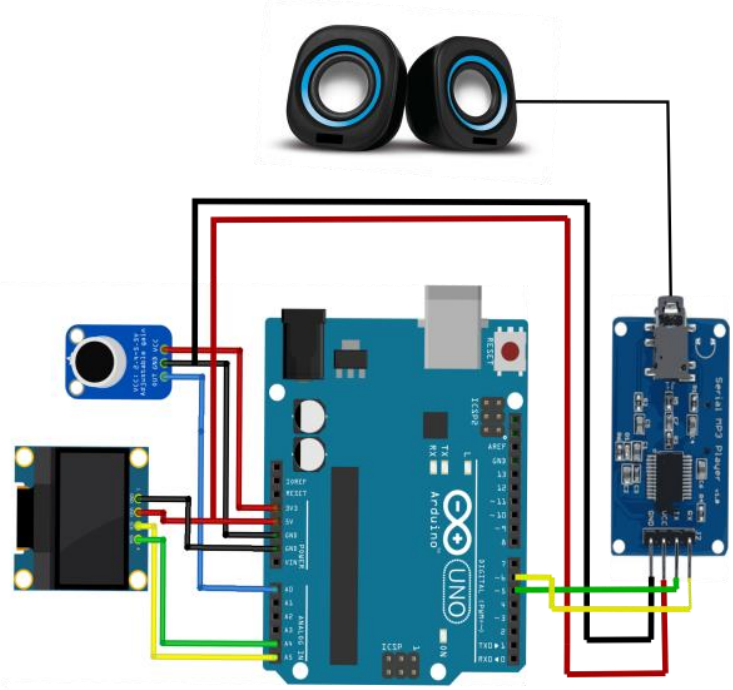

Gambar 3.3. Skematik Rangkaian

Pada gambar diatas merupakan skematik rangkaian prototype alat dimana Arduino Uno 328P sebagai inti dari alat pendeteksi dan pemberi peringatan kebisingan suara yang didukung sensor suara GYMAX4466 dan modul MP3 Player Catalex YX5300. Sebagai keluaran (output) dari alat ini adalah layar OLED 128x64 pixel sebagai pemberi peringatan berupa warning text dan speaker subwoofer sebagai peringatan berupa suara.

\subsection{Rangkaian Alat Prototype Secara Keseluruhan}

Rangkaian alat pendeteksi dan pemberi peringatan kebisingan suara yang telah dibuat menggunakan komponen utama Arduino Uno 328P yang didukung dengan sensor suara GY-MAX446 yang telah disatukan dengan menggunakan media plastik yang berukuran $12 \mathrm{~cm} \mathrm{x} 12 \mathrm{~cm} \times 9.5 \mathrm{~cm}$.

Gambar 3.4 Berikut merupakan tampilan alat dari depan yang telah dibuat. Terdapat layar OLED $128 \times 64$, port USB-B, port supply daya dan port audio $3.5 \mathrm{~mm}$ yang nantinya dihubungkan dengan speaker subwoofer. 


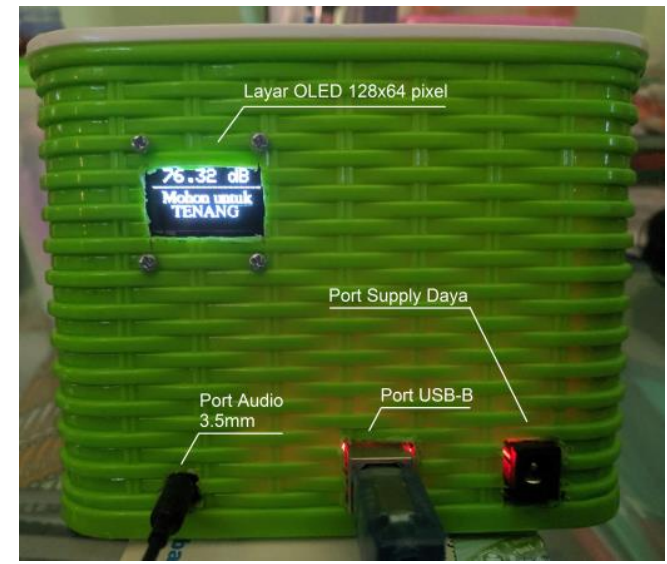

\section{Gambar 3.4. Alat Tampak Depan}

Gambar 3.5 Berikut merupakan tampilan alat dari arah samping yang telah dibuat. Terdapat sensor suara GY-MAX4466 yang mempunyai fungsi untuk mendeteksi tingkat kebisingan suara.

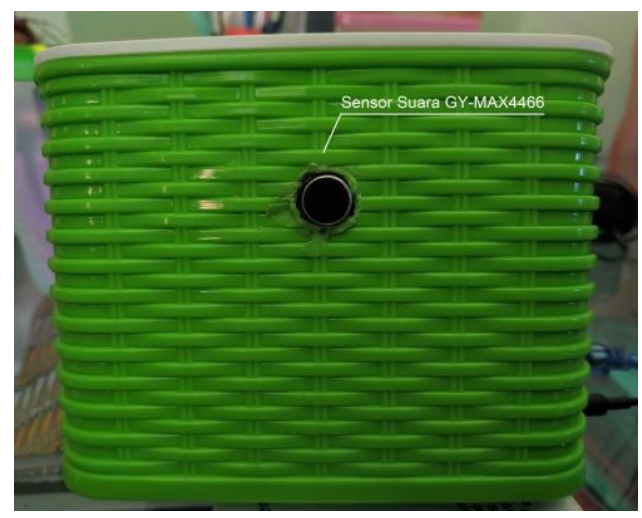

\section{Gambar 3.5. Alat Tampak Samping}

Gambar 3.6 Berikut merupakan tampilan alat dan speaker subwoofer yang telah dipasang melalui audio jack $3.5 \mathrm{~mm}$

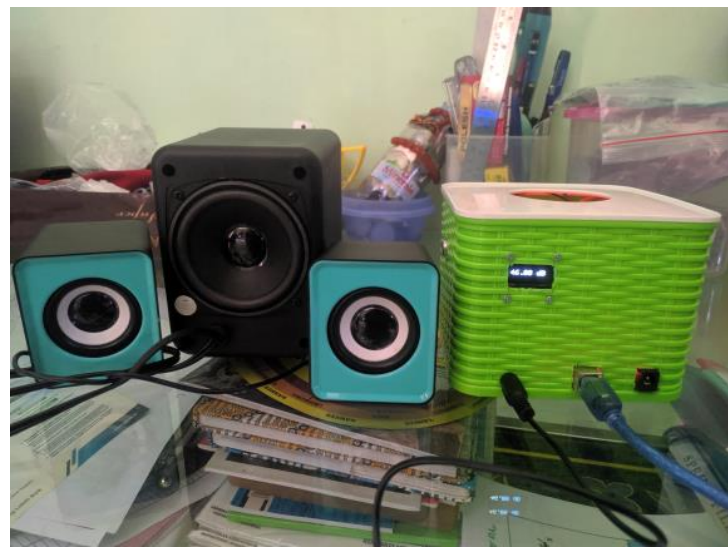

Gambar 3.6 Rangkaian Alat dan Speaker Subwoofer 


\subsection{Pengujian Alat dan Sistem}

Pengujian ini ditujukan untuk mengetahui tingkat desibel suara dari pembacaan sensor suara GYMAX4466. Pada pengujian sensor suara GY-MAX4466, peneliti melakukan pengujian menggunakan berbagai sumber suara dan jarak yang berbeda-beda yaitu 1 meter, 3 meter dan 5 meter, cara ini dilakukan karena jarak antara sumber bunyi dengan alat berpengaruh pada tingkat desibel suara. Pengujian dilakukan ditempat yang sunyi dan tenang agar dihasilkan pengukuran yang akurat. Berikut merupakan hasil pengujian sensor suara GY-MAX4466.

Tabel 3.1 Hasil Pengujian Dengan Jarak 1 Meter

\begin{tabular}{|l|l|l|l|l|}
\hline No & Sumber Suara & Hasil Deteksi & Nilai Desibel & Peringatan \\
\hline 1 & Suara manusia bicara & Baik & 58.72 & Menyala \\
\hline 2 & Suara music handphone & Baik & 56.96 & Menyala \\
\hline 3 & Suara tepuk tangan & Baik & 78.11 & Menyala \\
\hline 4 & Hembusan Angin & Tidak Baik & - & Tidak Menyala \\
\hline 5 & Suara Siulan & Baik & 60.89 & Menyala \\
\hline
\end{tabular}

Dari hasil pengujian pertama dapat dilihat bahwa sensor suara dapat dengan baik mendeteksi 4 sumber suara dengan jarak 1 meter dan hanya 1 sumber suara yang tidak dapat dideteksi dengan baik yaitu hembusan angin. Nilai desibel sangat bervariasi tergantung dengan tinggi rendahnya suara.

Tabel 3.2 Hasil Pengujian Dengan Jarak 3 Meter

\begin{tabular}{|l|l|l|l|l|}
\hline No & Sumber Suara & Hasil Deteksi & Nilai Desibel & Peringatan \\
\hline 1 & Suara manusia bicara & Baik & 56.79 & Menyala \\
\hline 2 & Suara music handphone & Baik & 56.03 & Menyala \\
\hline 3 & Suara tepuk tangan & Baik & 68.02 & Menyala \\
\hline 4 & Hembusan Angin & Tidak Baik & - & Tidak Menyala \\
\hline 5 & Suara Siulan & Baik & 58.12 & Menyala \\
\hline
\end{tabular}

Dari hasil pengujian kedua dapat dilihat bahwa sensor suara masih dapat dengan baik mendeteksi 4 sumber suara dengan jarak 3 meter dan hanya 1 sumber suara yang tidak dapat dideteksi dengan baik yaitu hembusan angin. Nilai desibel yang terdeteksi sedikit mengalami penurunan karena jarak antara alat dan sumber suara semakin bertambah.

Tabel 3.3 Hasil Pengujian Dengan Jarak 5 Meter

\begin{tabular}{|l|l|l|l|l|}
\hline No & Sumber Suara & Hasil Deteksi & Nilai Desibel & Peringatan \\
\hline 1 & Suara manusia bicara & Baik & 55.42 & Menyala \\
\hline 2 & Suara music handphone & Baik & 55.63 & Menyala \\
\hline 3 & Suara tepuk tangan & Baik & 62.44 & Menyala \\
\hline 4 & Hembusan Angin & Tidak Baik & - & Tidak Menyala \\
\hline 5 & Suara Siulan & Baik & 56.31 & Menyala \\
\hline
\end{tabular}

Dari hasil pengujian ketiga dapat dilihat bahwa sensor suara masih dapat dengan baik mendeteksi 4 sumber suara dengan jarak 5 meter dan hanya 1 sumber suara yang tidak dapat dideteksi dengan baik yaitu hembusan angin. Nilai desibel pada pengujian ketiga sangat mendekati nilai normal yaitu 55, ini menandakan jarak sangat mempengaruhi terhadap pembacaan nilai desibel. 


\section{KESIMPULAN}

Berdasarkan dari keseluruhan sistem yang telah dirancang, penulis memiliki beberapa kesimpulan diantara lain:

1) Telah berhasil merancang suatu prototype alat pendeteksi dan pemberi peringatan kebisingan suara berbasis Arduino.

2) Hasil pengujian terhadap alat dan sistem menunjukan semua fungsi telah berjalan dengan baik dan sesuai. Hasil tersebut diantaranya telah berhasil mendeteksi dan menampilkan nilai desibel dan memberi peringatan berupa warning text dan suara jika terjadi kebisingan didalam ruangan Perpustakaan Universitas AMIKOM Purwokerto.

3) Sumber dan jarak suara sangat menentukan keakuratan pembacaan nilai desibel karena semakin jauh suara akan terdeteksi semakin lemah.

4) Nilai desibel yang ditampilkan berkisar $40-80 \mathrm{~dB}$

\section{DAFTAR PUSTAKA}

[1] Hakim, R. (2014). Komponen Perancangan Arsitektur Lansekap. Jakarta: PT Bumi Aksara.

[2] Hakim, R. (2014). Komponen Perancangan Arsitektur Lansekap. Jakarta: PT Bumi Aksara.

[3] Djalante, S. 2010. “Analisis Tingkat Kebisingan Jalan Raya Yang Menggunakan Alat Pemberi Isyarat Lalu Lintas (APIL) (Studi Kasus: Simpang Ade Swalayan). Jurnal SMARTek, Vol. 8 No. 4, 280-300.

[4] Buchari. (2007). Kebisingan Industri dan Hearing Conservation Program. Medan: Universitas Sumatra Utara.

[5] Bisrul Hapis Tambunan, I. K. 2014. "Usaha Mengurangi Kebisingan Knalpot Produksi IKM di Kota Medan". Jurnal Dinamis Vol. II, No.14, 1-7.

[6] Keputusan Menteri Lingkungan Hidup. (1996). Keputusan Menteri Negara Lingkungan Hidup No. Kep-48/MENLH/1/1996 tentang Baku Tingkat Kebisingan Sekretariat Negara, Jakarta.

[7] Nurwati. 2018. "Pendeteksi Tingkat Kebisingan Dan Pemberi Peringatan Pada Perpustakaan”. Seminar Nasional Royal (SENAR) STMIK Royal - AMIK Royal, 295-298. 